\title{
Experimental Evaluation of a Single Slope Solar Still
}

\section{Evaluación Experimental de un Destilador Solar de una Sola Pendiente}

\author{
Alfonso Santos Jaimes ${ }^{1 *}$, Emil Hernández Arroyo ${ }^{1}$, Zulma Y. Ramírez Jaimes ${ }^{2}$ \\ ${ }^{1}$ Ingeniería Mecánica, Universidad Pontificia Bolivariana, Bucaramanga, Colombia. \\ ${ }^{2}$ Ingeniería Electromecánica, Unidades Tecnológicas de Santander, Bucaramanga, Colombia
}

\begin{abstract}
In Colombia, there exist regions where they have wells, public cells or rivers as water resource. For this reason, there is the need of developing and evaluating mechanisms that allows improve water physical, chemical and microbiological conditions, used for human consumption in these regions. This paper describes the operation, the energy balance, the construction and tests of a prototype of single-slope solar distiller used to determine the influence of temperatures, thickness of condenser and water level inside the collector on thermal efficiency of the process of water distillation. The prototype was tested on noncontrolled environmental conditions at the city of Bucaramanga, measuring temperature, solar radiation and volume of distilled water. The trend lines gotten between volume of water distilled as a function of the incident solar radiation, the temperature difference between water and inner air in the distiller and between air and condenser on real operation condition, allowed the identification of optimal design parameters. After analyzing the results, it was observed a linear dependence between solar radiation and volume of water distilled, in addition to a dependence to the distilled volume to the difference of water temperatures, inner air and the condenser inside the distiller.
\end{abstract}

Keywords: Distillation, Distiller Design, Thermal Efficiency, Solar Energy, Solar Radiation.

\section{Resumen}

En Colombia, existen poblaciones que tienen pozos, pilas públicas y ríos como fuente de aprovisionamiento de agua. Por esta razón, surge la necesidad de desarrollar y evaluar mecanismos que permitan mejorar las condiciones físicas, químicas y microbiológicas del agua que se utiliza para consumo humano en estas regiones. Este artículo describe el funcionamiento, el balance energético, la construcción y pruebas de un prototipo de destilador solar de una sola pendiente, cuyo uso es la determinación de la influencia de las temperaturas, el espesor del condensador y el nivel del agua dentro del colector en la eficiencia térmica del proceso de destilación de agua. El prototipo fue probado en condiciones medioambientales no contraladas en la ciudad de Bucaramanga, midiendo temperatura, radiación solar y volumen de agua destilada. Las líneas de tendencia obtenidas entre el volumen destilado en función de la radiación solar incidente, la diferencia de temperatura entre el agua y el aire interno del destilador, y entre el aire y el condensador en condiciones reales de funcionamiento, permitieron definir los parámetros de diseño óptimo. Después de analizados los resultados, se observó una relación lineal entre la radiación solar y el volumen destilado, además de una dependencia del volumen destilado con las diferencias de temperaturas presentes entre el agua, el aire y el condensador dentro del destilador.

Palabras clave: Destilación, Diseño de Destiladores, Eficiencia Térmica, Energía Solar, Radiación Solar.

*Corresponding Author.

E-mail: alfonso.santos@upb.edu.co
How to cite: Santos, A., Hernández, E., Ramírez, Z., Experimental Evaluation of a Single Slope Solar Still, TECCIENCIA, Vol. 12 No. 22, 63-71, 2017

DOI: http://dx.doi.org/10.18180/tecciencia.2017.22.7 


\section{Introduction}

Solar stills are systems of easy operation and low cost that, through the use of energy supplied by the sun, rise the water temperature for a sufficient period of time in equipped containers to achieve the absorption of heat from radiation [1]; for this reason these equipment may represent a viable alternative for disinfection of water [2] for human consumption from sources without any purification treatment.

The solar distiller is the best known and widespread in the world and consists of a semi-transparent material topped box, usually glass, which is placed on a tray containing water to be distilled. For the geometry of the box and the way it traps heat from solar energy it has earned them the name of "greenhouses distillers".

The "greenhouse" effect causes the temperature inside rises to the order of 50 to $60{ }^{\circ} \mathrm{C}$ [3]. When these equipment have water sheets of 1.5 to $2 \mathrm{~cm}$ thick, under high insolation conditions, low ambient air temperature and substantial winds $(2 \mathrm{~m} / \mathrm{s}$ or more) produce up to 3 to $5 \mathrm{~L}$ of distilled water per square meter of surface every day. The characteristic value of production of solar distillers is of the order of $1 \mathrm{~m}^{3}$ of water catchment per year [4] [5].

Most studies to solar distillers show a direct dependence on environmental conditions in the areas where would be implemented this kind of equipment; due to this and the absence of verifiable information, for the municipality of Bucaramanga, on appropriate conditions of operating parameters that directly influence the system efficiency, it is necessary to implement a prototype that allows to determine how it affects each of these parameters, the harnessing of this renewable energy source.

The dependence of the degree of bacteriological disinfection achieved with respect to the level of water contained within the evaporator collector, suggests the use of containers up to $10 \mathrm{~cm}$ depth in order to obtain greater disinfection efficiency in less time of sun exposure of the equipment [6].

The thermal efficiency of a solar distiller is defined as the quotient between the heat transferred from the evaporator to the condenser by evaporation-condensation mechanism, divided between irradiation during the testing period. A way to measure evaporative heat condensation is to quantify the volume of distillate and multiply by the evaporation latent heat [7].

Theoretically and experimentally, it has been shown that solar distillers have a maximum percent efficiency in the order of 30 to $35 \%$ [8] [9] [10], value that depends not only on atmospheric factors such as: the amount of solar radiation, environment temperature and wind speed, but also the design of the solar distiller.

Insofar as the water level within the collector-evaporator is minimized, is possible to maximize the distillate production; also, the difference in evaporation time of 50 milliliters of water in sheets of 8 and $12 \mathrm{~mm}$ is not considerable, therefore is recommended the use of water levels of $10 \mathrm{~mm}$ within the distiller [11].

The atlas of solar radiation in Colombia [12] determined that, in Colombian territory solar radiation varies between 2.5 and $7.0 \mathrm{~kW} / \mathrm{m}^{2}$ day, which represents an energy potential that can be used for the purpose of imitating the natural process of water purification through the hydrologic cycle.

\section{Operation}

The operation of a solar distiller is based on the capability of the air the atmosphere of containing water vapor. The air can be considered as a mixture of water vapor and dry air, because the composition of dry air remains relatively constant, but the amount of water vapor can vary depending on the condensation and evaporation of oceans, lakes, rivers, watering cans and even the human body [13].

The specific humidity increases as more steam or humidity is added to air until it can no longer hold more humidity, at this point it is said that the air is saturated with humidity. Any humidity added to the saturated air will be condensed. The relative humidity varies from 0 for dry air at 1 for saturated air; it is important to remember that the amount of humidity that the air can hold depends on its temperature. Therefore, the relative humidity changes with temperature although its specific humidity remains constant [14] [15].

In a solar distiller, the water is deposited in a container located in the bottom where it is heated by the absorption of the solar radiation; as temperature increases the water begins to evaporate which causes an increase in the humidity of air contained in the distiller.

The humid hotter air rises to a cooler transparent cover on which surface part of the water vapor is condensed, sliding downwards and falling into the canal intended to collect water leaving the salt and other minerals (non-evaporable at low temperature) in the vessel.

This process occurs continuously while the distiller is receiving solar energy. The water from the canals can be collected in containers placed outside the distiller. See Figure 1. 


\section{TECCIENCLA}

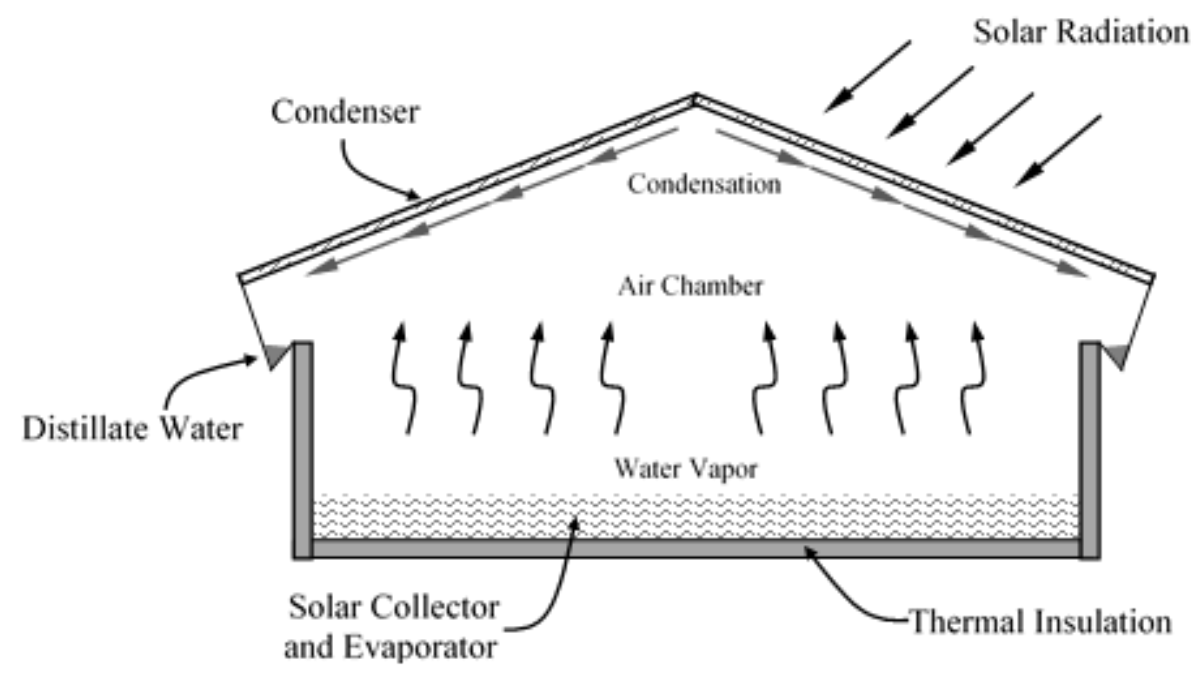

Figure 1. Air flow inside the solar distiller.

\section{Mathematical Model of a Solar Distiller}

The energy conservation equations (1) and (2) applied to the roof and the water, referring to Figure 2, are:

$$
\begin{gathered}
q_{c}^{\prime}=q_{r w}+q_{c w}+q_{e}+\alpha g * I_{T}-\left(q_{r v}+q_{c v}\right) \\
q_{a}^{\prime}=I_{T} *(1-\alpha g)(1-\alpha a)-\left(q_{r w}+q_{c w}+q_{e}+q_{c}\right)
\end{gathered}
$$

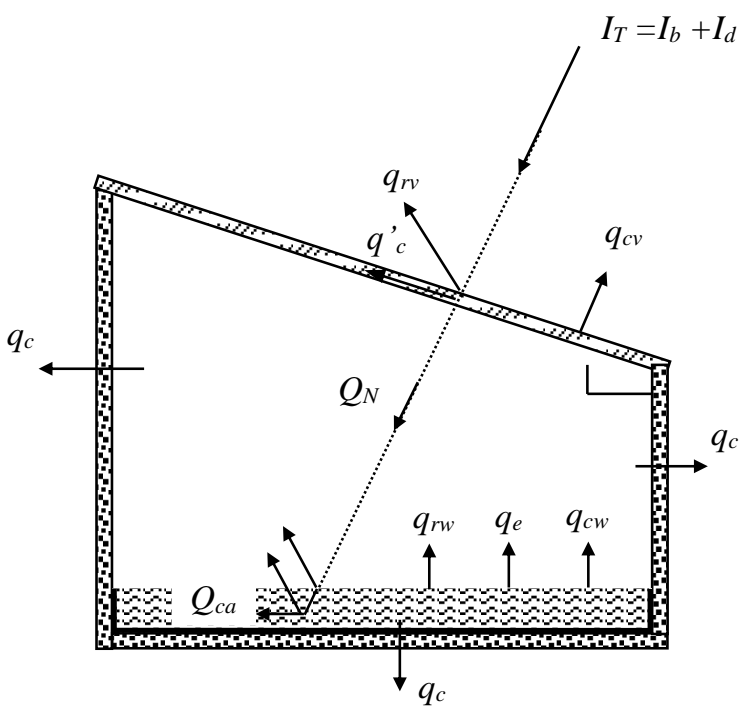

Figure 2. Energy balance in a stall solar distiller.
Where:

$q_{c}^{\prime}=$ Heat stored by the cover $\left(\mathrm{W} / \mathrm{m}^{2}\right)$

$q_{r w}=$ Heat lost by radiation $\left(\mathrm{W} / \mathrm{m}^{2}\right)$

$q_{c w}=$ Heat lost by the convection of water $\left(\mathrm{W} / \mathrm{m}^{2}\right)$

$q_{e}=$ Heat lost by evaporation $\left(\mathrm{W} / \mathrm{m}^{2}\right)$

$I_{T}=$ Direct radiation on a sloping surface $\left(\mathrm{W} / \mathrm{m}^{2}\right)$

$\alpha \mathrm{g}=$ Factor of reflection of the radiation

$q_{r v}=$ Heat lost by radiation from the glass $\left(\mathrm{W} / \mathrm{m}^{2}\right)$

$q_{c v}=$ Heat lost by convection of glass $\left(\mathrm{W} / \mathrm{m}^{2}\right)$

$q_{a}^{\prime}=$ Heat stored by water $\left(\mathrm{W} / \mathrm{m}^{2}\right)$

$\alpha \mathrm{a}=$ Coefficient that includes the reflection and the absorption of the solar radiation by the water and by the bottom of the distiller.

$q_{c}=$ Heat lost by conduction $\left(\mathrm{W} / \mathrm{m}^{2}\right)$

The total heat stored per unit of area of distiller is related in equation (3)

$$
q_{t}=q_{c}^{\prime}+q_{a}^{\prime}
$$

Equation (4) expresses the heat capacity stored by the manifold as a function of the area

$$
Q_{T}=q_{t} * A
$$

Where:

$Q_{T}=$ Heat absorbed by the solar distiller $(\mathrm{W})$

$A=$ Catchment area of solar radiation $\left(\mathrm{m}^{2}\right)$

The amount of heat absorbed by the glass to raise its temperature is obtained from equation (5)

$$
Q_{c v}=m_{v} * C_{p v}\left(T_{v}-T_{a}\right)=\rho_{v} * A_{v} * e_{v} * C_{p v}\left(T_{v}-T_{a}\right)
$$




\section{TECCIENCIA}

Where:

$Q_{c v}=$ Amount of heat needed to heat the glass (J)

$m_{v}=$ Mass of glass $(\mathrm{kg})$

$e_{v}=$ Glass Thickness (m)

$C_{p v}=$ Specific heat of glass $(\mathrm{J} / \mathrm{kgK})$

$T_{a}=$ Room temperature $\left({ }^{\circ} \mathrm{C}\right)$

$T_{v}=$ Temperature of equilibrium of glass $\left({ }^{\circ} \mathrm{C}\right)$

$\rho_{v}=$ Density of glass $\left(\mathrm{kg} / \mathrm{m}^{3}\right)$

$A_{v}=$ Area of the glass $\left(\mathrm{m}^{2}\right)$

The amount of heat required to heat and evaporate the water from the tray is obtained from equations (6) and (7) respectively

$$
\begin{gathered}
Q_{c a}=m_{a} * C_{p a} *\left(T_{w}-T_{a}\right) \\
Q_{e v}=x * m_{a} * \lambda
\end{gathered}
$$

Where:

$Q_{c a}=$ Amount of heat needed to heat the water (J)

$m_{a}=$ Mass of water in the manifold $(\mathrm{kg})$

$C_{p a}=$ Specific heat of water $(\mathrm{J} / \mathrm{kgK})$

$T_{w}=$ Temperature of equilibrium of water $\left({ }^{\circ} \mathrm{C}\right)$

$Q_{e v}=$ Amount of heat needed to evaporate x percentage of water $(\mathrm{J})$

$x=$ Percentage of evaporated mass $\lambda=$ Enthalpy of vaporazation at temperature $T_{w}(\mathrm{~J} / \mathrm{kg})$

The amount of heat needed to heat the glass, the water on the tray and evaporate a percentage of it, is obtained from equation (8)

$$
Q_{N}=Q_{c v}+Q_{c a}+Q_{e v}
$$

Where:

$Q_{N}=$ Total heat needed $(\mathrm{J})$

\section{Methodology}

In order to select the variables that influence the performance of the solar distiller, simulations are performed based on the mathematical models that were obtained for the amount of heat needed to heat the glass, to heat and evaporate the water and the total heat needed; The simulations were performed with the following data: density of glass $(2500 \mathrm{~kg} / \mathrm{m} 3)$, density of water $(983.13 \mathrm{~kg} / \mathrm{m} 3)$, specific heat of glass $(837 \mathrm{~J} / \mathrm{kg} \mathrm{K})$, specific heat of water $(4186 \mathrm{~J} / \mathrm{kg} \mathrm{K})$, enthalpy of vaporization of water $(2258$ $\mathrm{kJ} / \mathrm{kg})$, glass area $(1 \mathrm{~m} 2)$, percentage of evaporated water mass $(10 \%)$, temperature of equilibrium of water $\left(60^{\circ} \mathrm{C}\right)$ y room temperature $\left(30^{\circ} \mathrm{C}\right)$. The results obtained as function of glass thickness and level of water are related on Figure 3.

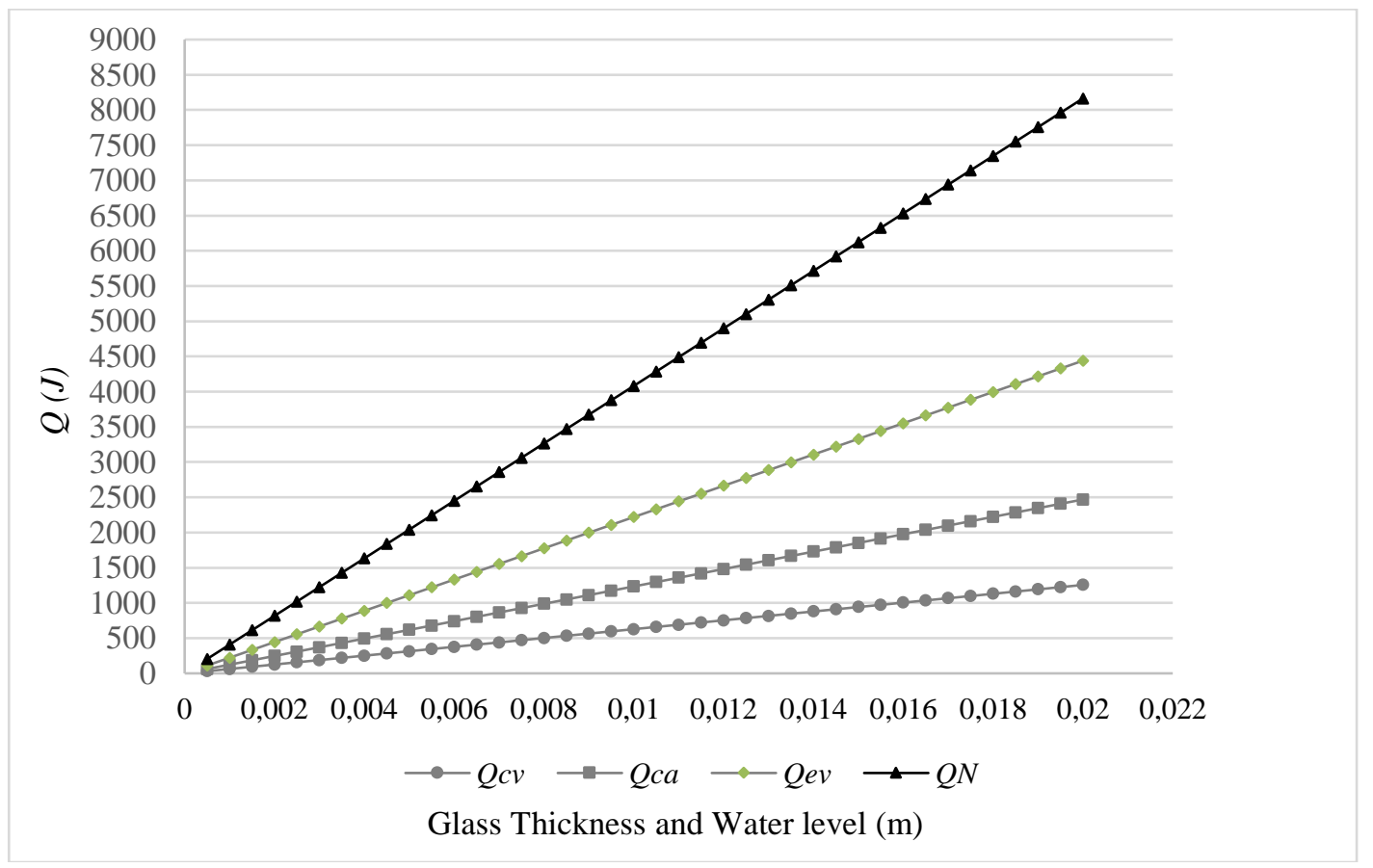

Figure 3. Simulation of heat necessary for the operation of a distiller as function of glass thickness and water level. 


\section{TECCIENCIA}

Figure 3 shows that there is a direct relation between the thickness of the glass and the heat needed to heat it which means that for greater thicknesses a large part of the solar energy supplied is used for this process, which decreases the distillation efficiency of the equipment. This same behavior is also appreciated with the water level.

Based on the above information, it is designed and built an experimental prototype of distiller, see Figure 4, based on a solar distiller with a single slope which consists of a collector-evaporator, a condenser, a condensate collection system and 3 temperature sensors, all mounted on a metal structure to facilitate shifting skate wheel system for conducting the tests.

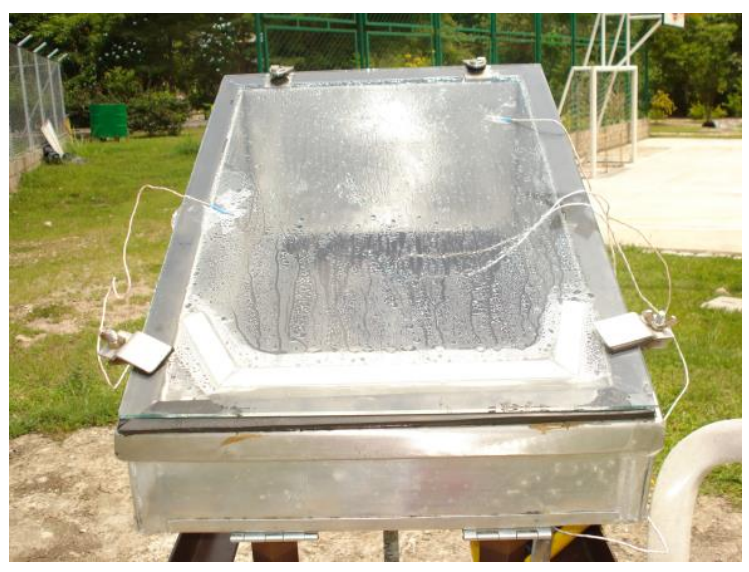

Figure 4. Distiller Built [Source: Author of project]

The collector-evaporator is in charge of accumulating heat generated by solar radiation and transfer it to water through conduction phenomenon; in this vessel the evaporation of water to distill occurs, due to an increase in water saturation pressure in the air caused by the temperature rise. This system was constructed of a sheet of zinc of $1 / 16$ " thick with an area of $0.093 \mathrm{~m}^{2}$ and a height of $0.1 \mathrm{~m}$, which was painted matt black to increase the ability to absorb energy in order to improve the utilization of solar radiation trapped by the distiller.

The condenser is responsible for lowering the temperature of air entering into contact with it, to produce a reduction in the amount of vapor present in the air through the condensation process. This system was constructed essentially using a glass sheet of $2 \mathrm{~mm}$ thick and an area of $0.119 \mathrm{~m}^{2}$, element that meets the basic requirements of condenser: transparent and rigid material that allows the passage of solar radiation from outside to inside distiller. The side walls of distiller have different heights, the back is $27 \mathrm{~cm}$ and the front $8.5 \mathrm{~cm}$ to give a slope of $20^{\circ}$ to condenser (glass) in order to allow the sliding of the distilled water drops to the collection channel which is coupled to a hose connected directly to a storage vessel.
In the collector-evaporator of solar distiller was supplied water from streams, for tests development. Then, the distiller was exposed to environmental uncontrolled conditions to take advantage of the existing solar radiation and cause the water evaporation-condensation process.

5 tests were performed for each of the levels $(0.5,1,1.5,2$, $3,5$ and $6 \mathrm{~cm})$. In each test the average solar radiation through a Pyranometer CM3 which has a sensitivity of 10$35 \mu \mathrm{V} / \mathrm{Wm}^{-2}$, water, air and glass temperature inside the distiller and the amount of distilled water with an analogous balance Sartorius model BP211 D of resolution $0.1 \mathrm{mg}$, during 7 hours of exposure of system to solar radiation, was measured. At the end of each test is determined the efficiency of the process during the day by equation (9), to define the influence of the level in the thermal efficiency of distiller, was averaged every five tests performed for each test parameter and the standard deviation was calculated.

$$
\eta_{\text {thermal }}=\frac{m_{d} * \lambda}{H_{s} * A_{v}}
$$

Where $m \_$dis the mass of distillate obtained in one day in $\mathrm{kg}$; $\lambda$ is the heat of vaporization of water $(\mathrm{kJ} / \mathrm{kg}) ; H_{-} s$ is the corresponding irradiation $\left(\mathrm{kJ} / \mathrm{m}^{2}\right)$ and $A v$ is the collector area in $\mathrm{m}^{2}$. By replacing equations (5-8) in equation (9), the thermal efficiency can be expressed as a function of glass thickness, water temperature, glass and ambient temperature, and the level of water inside the distiller $(h a)$, as related in equation (10).

$$
\begin{aligned}
\eta_{-} t h e r m a l & =\left(Q_{-} N-\left[\rho _ { - } v * A _ { - } v * e _ { - } v * C _ { - } p v \left(T_{-} v\right.\right.\right. \\
& \left.-T_{-} a\right)+\rho_{-} a * A_{-} a * h_{-} a * C_{-} p a\left(T_{-} w\right. \\
& \left.\left.\left.-T_{-} a\right)\right]\right) /\left(H_{-} S * A_{-} v\right)
\end{aligned}
$$

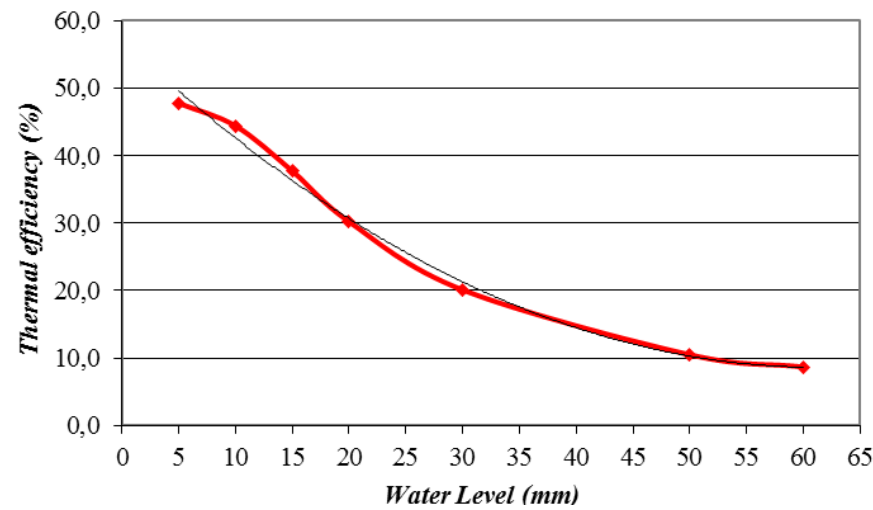

Figure 5. Average thermal efficiency of distiller in function of water level inside collector-evaporator [Source: Author of project] 


\section{TECCIENCIA}

\section{Results}

The tests performed to the solar distiller with different water levels contained within the collector- evaporator, allow to check that the process efficiency is inversely proportional to this variable and can be related by a second order polynomic equation, as seen in Figure 5.

Equation (10) models theoretically the influence of glass thickness on thermal efficiency and expresses that the higher this variable, the heat stored by the roof increases, which causes a decrease in the use of the solar irradiation present and by consequently a reduction of distillation process. This behavior allows to recommend the use of water level between 5 and $10 \mathrm{~mm}$ without ignoring that this entails an increase in the exposure area and therefore a higher cost in the distiller construction.

Figure 6 shows the dependence of the distiller efficiency in function of the condenser thickness (glass), the tests were carried out with a water level of $5 \mathrm{~mm}$ and shows an inversely proportional relationship between these two variables and can be related through a lineal equation.
Equation (6) defines a direct relation between the heat required to heat the water and the amount of water stored in the distiller; as the collector area is constant the only way to decrease this heat is to reduce the height of the water level and consequently a higher thermal efficiency of the process can be achieve, as is theoretically expressed in equation (10).

The maximum thermal efficiency obtained in the distiller for a water level within the collector - evaporator, of $5 \mathrm{~mm}$ and a $2 \mathrm{~mm}$ thickness of the condenser was $46,9 \%$. The incident solar radiation influences directly proportional in the volume of distilled water in the process, regardless of the condenser thickness used, as shown in Figure 7; this agrees with the mathematical modeling of the thermal efficiency of the distiller expressed in equation (10) and of the heat absorbed by the water of equation (2).

It can also be observed that the slope of the line is grater for a condenser thickness of $2 \mathrm{~mm}$, representing a greater distilled water volume for the same radiation condition and therefore higher thermal efficiency in the distillation process through solar energy.

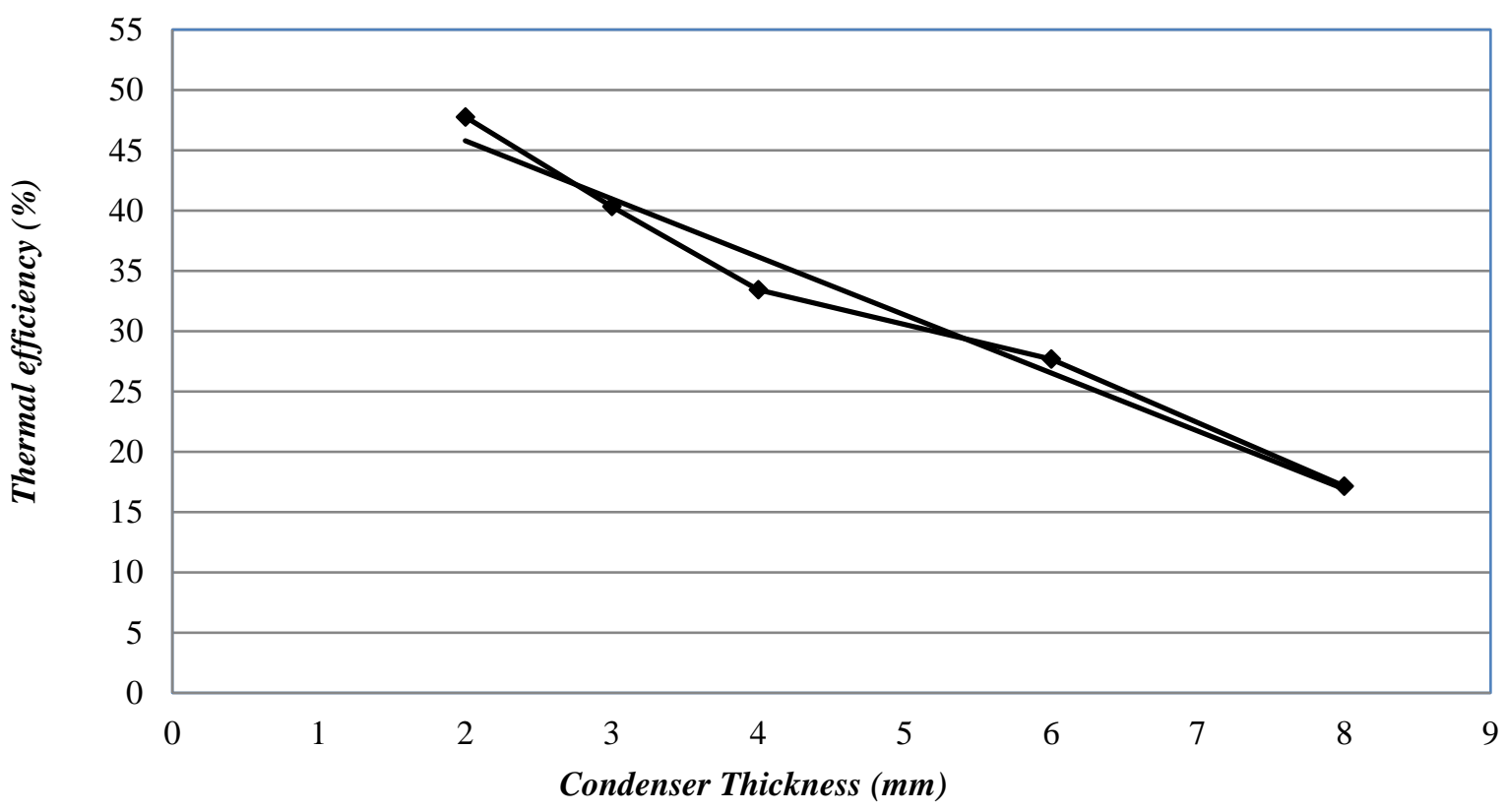

Figure 6. Average thermal efficiency of distiller in function of condenser thickness [Source: Author of project] 


\section{TECCIENCIA}

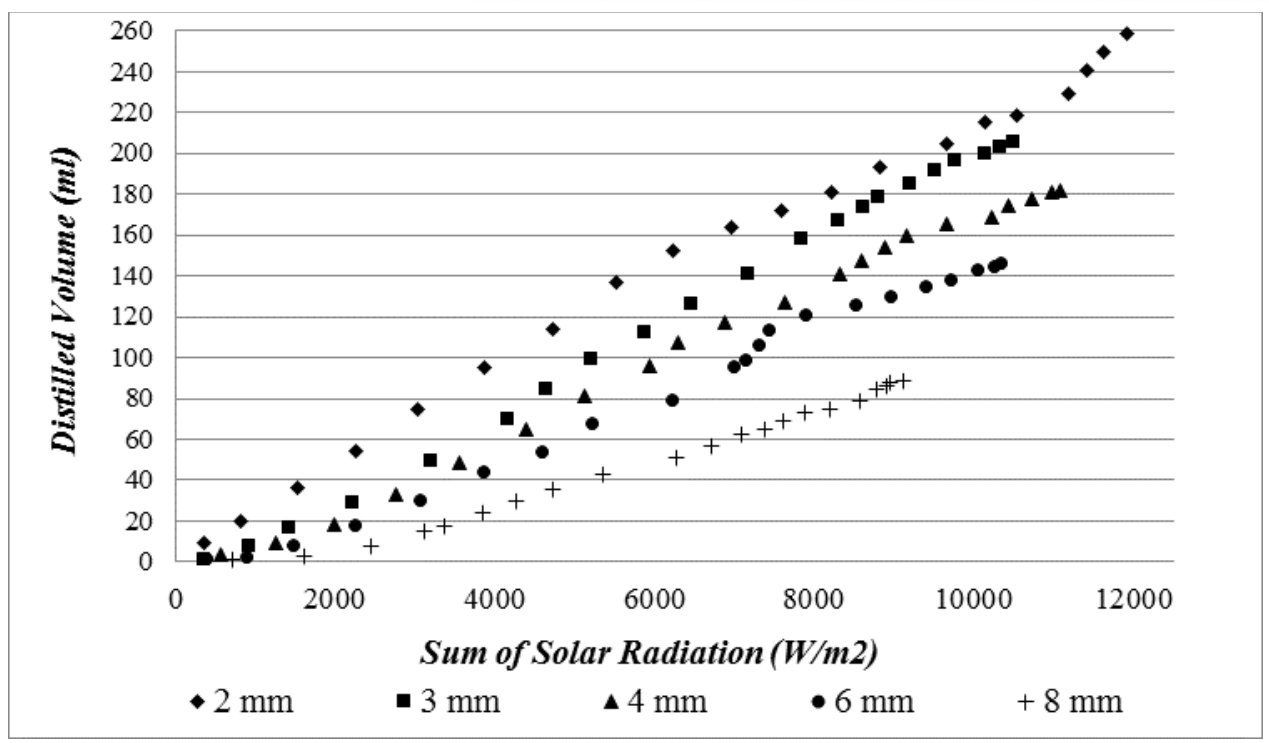

Figure 7. Volume of distilled water in function of incident solar radiation sum, for different condenser thickness.
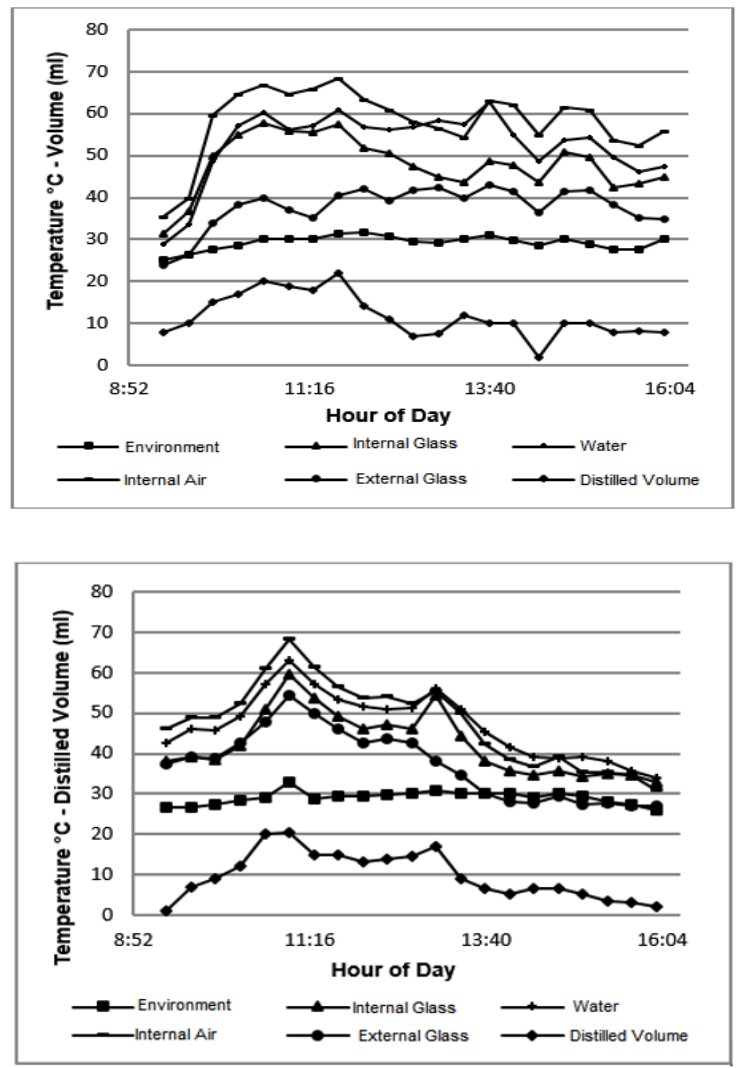

Figure 8. Influences of temperature: environment, internal glass, water, internal air and external glass into the volume of distilled water for a) condenser of $2 \mathrm{~mm}$ thick and b) condenser of $3 \mathrm{~mm}$ thick.
The maximum volume of distillate obtained during the tests performed was 267.7 milliliters, representing a productivity of $2.68 \mathrm{~L} / \mathrm{m}^{2}$ with an average radiation of $580.5 \mathrm{~W} / \mathrm{m}^{2}$ during 7 hours of testing between 9:00 am and 4:00 pm. Figure 8 (a) and (b) shows the behavior of the process temperatures during the development of tests for condenser 2 and 3 respectively and it shows that the value of the environmental temperature remains practically constant during all the time interval.

Glass temperatures (internal and external), the water and internal air have a fluctuation behavior but always above environmental conditions, allowing to check the greenhouse effect within the distiller and which gives rise to an atmosphere at high temperature and saturated humidity. The behavior of the distillate volume presents a trend quite similar to the temperatures present in the distiller, which allows to infer a direct proportional influence among these variables.

The equations of heat transfer applied to a distiller, allow to infer a dependency of the distillate volume with respect to temperature variations in water, internal air and glass, as expressed in equations (5), (6) and (10).

Figure 9 (a) and (b) shows a dependence between the temperature difference reached in the internal air of the distiller and the water contained in the collector evaporator, with respect to distilled volume, regardless of the thickness of the condenser used. 


\section{TECCIENCIA}

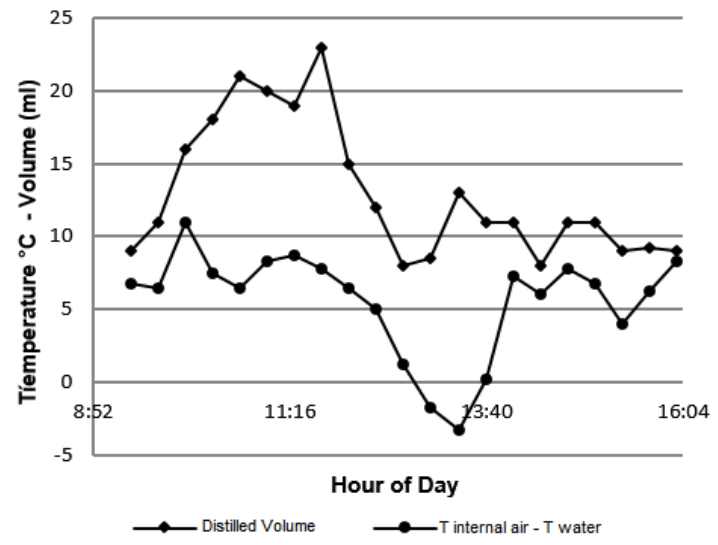

(a)

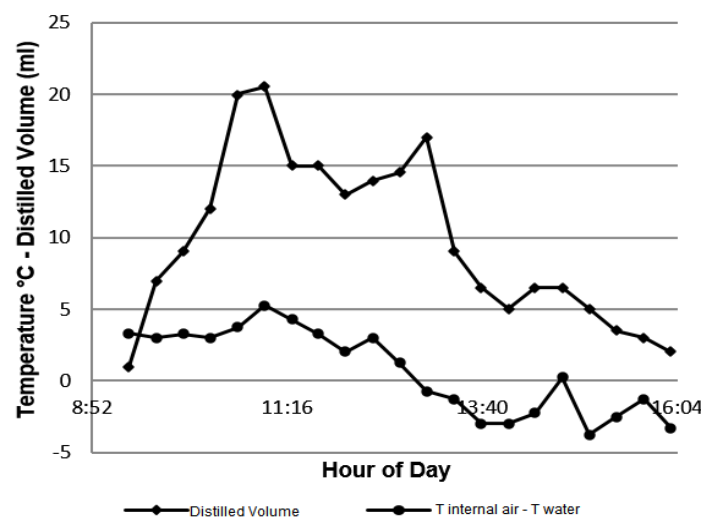

(b)

Figure 9. Influences of temperature difference between the internal air and water distiller in the distilled water volume to a) condenser of $2 \mathrm{~mm}$ thick and b) condenser of $3 \mathrm{~mm}$ thick.

\section{Discussion}

The results obtained during the simulation of the theoretical equations and experimental development allow to identify the influence of the water level in the collector - evaporator, the thickness of condenser, solar radiation and the temperatures reached inside the distiller, in the distilled water volume during the process and therefore in it thermal efficiency.

Al-Hayek, et al. [16] concluded that the productivity of a solar distiller can be increased by a decrease in the level of water in the collector - evaporator, supported by Abdul et al. [17] who said in a recent paper that the productivity in a solar distiller can be reduced by up to $33 \%$ when the water level varies from 1 to $10 \mathrm{~cm}$.

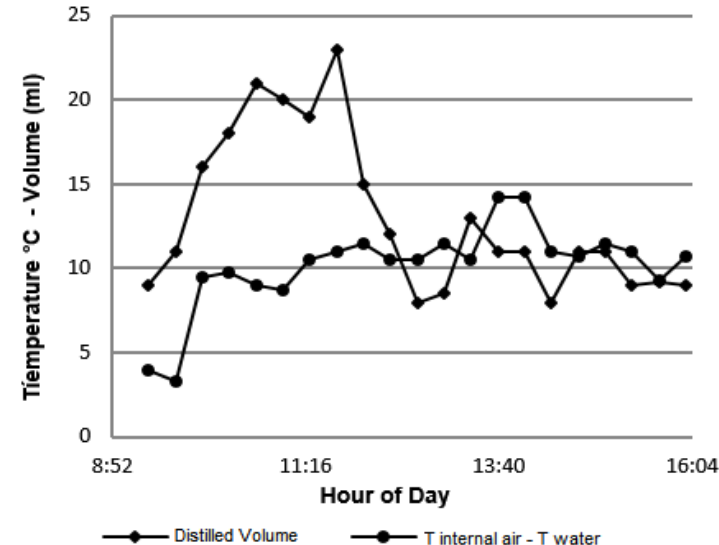

(a)

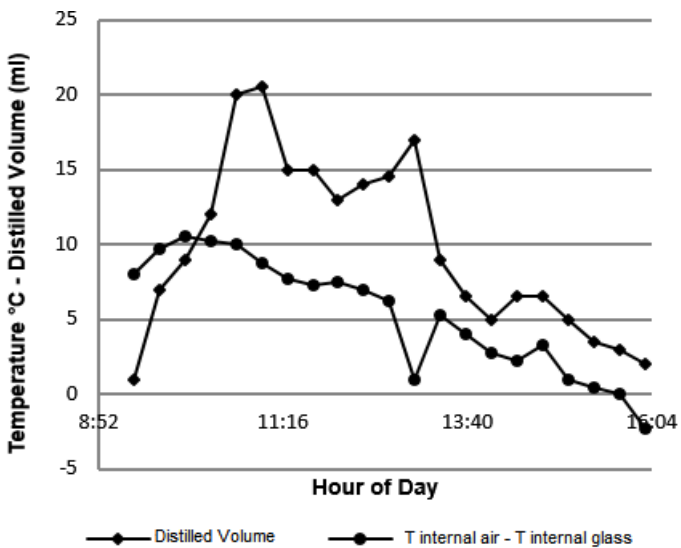

(b)

Figure 10. Influences of temperature difference between the internal air and the inner surface of the roof in the volume of distilled water for a) condenser of $2 \mathrm{~mm}$ thick and $b$ ) condenser of $3 \mathrm{~mm}$ thick [Source: Author of project]

These statements corroborate the results obtained in the development of this research project, which was developed in the municipality of Bucaramanga (Colombia) and which are reflected in the Figure 5. This information allows to have support when sizing a solar distiller because it restricts one of the variables involved in the design as is the height of the collector - evaporator.

The thickness of the condenser influences inversely proportional the efficiency of the solar distiller, as shown in Figure 6; this information provides the designer with an additional tool to size the distiller depending on the requirements of water to distill per day. The material of the condenser used was glass which has the disadvantage of being fragile and for rural applications might not be the best 
option; due to this is necessary to determine the behavior of the distiller with condensers made of other materials.

Zaki, et al [18] and Abdul, et al [17] assert that the productivity of a solar distiller increases with increasing intensity of solar radiation received, these results are consistent with those obtained in the tests performed and are listed in Figure 7; this information restricts their use to areas where high solar radiation values as deserts, coasts and equatorial regions are present.

Figure 8,9 and 10 show a dependence of the distillate volume with respect to the temperatures present in the solar distiller, this trend was also presented by Rahul, et al [19] who observed that both the gain and the instantaneous efficiency loss are dependent on design factor which relates the temperature difference between water and the air above the value of the radiation intensity.

This information allows to identify the need for materials that absorb heat well for manufacturing the collector evaporator and the used of thermal insulation for the walls of the distiller in order to achieve the highest values of temperature within the system.

\section{Conclusions}

The thermal efficiency of distillation system is influenced by the water level in the collector - evaporator of the distillation equipment. The maximum efficiency achieved with the built distiller was $46.9 \%$ when the water level within the collector - evaporator is $0.5 \mathrm{~cm}$; this value decreases exponentially to a value of $8.7 \%$ when the water level is $6 \mathrm{~cm}$.

The efficiency of a solar distiller depends inversely of the condenser (glass) thickness used in the process and have a linear dependence between the two variables involved.

The water temperature, the internal air, the glass (internal and external) and the temperature differences between these variables have directly proportional influence to the thermal efficiency of the solar distiller.

In the design of a solar distiller is necessary to consider the environmental conditions where is wanted to implement this type of equipment but considering design factors (dimensions and materials to use) required to obtain an attractive solution for the user.

\section{References}

[1] Márquez Bravo, Lydia G. (1998). Desinfección Solar. En memorias de Simposio Regional sobre Calidad del Agua: Desinfección Efectiva. Lima, CEPISOPS, p.1-22. Consultado el 14 de mayo de
2016

http://www.bvsde.paho.org/bvsacg/e/fulltext/simposio/ponen14.pdf

[2] A. Shukla, Karunesh Kant and Atul Sharma (2017). Solar Still with latent heat energy storage: A review. Innovative Food Science and Emerging Technologies, 41, $34-46$

[3] Álvarez, Manuel (2007). La Destilación Solar, una posibilidad real de utilización en cuba. Consultado el 12 de enero de 2017 en http://www.cubasolar.cu/biblioteca/energia/Energia16/HTML/artic ulo03.htm

[4] Abdallah Salah, Abu- Khader Mazen M, Badran Omar (2009). Effect of various absorbing materials on the thermal performance of solar stills. Desalination, 242, 128-37.

[5] Elango T, Kalidasa Murugavel K. (2015). The effect of the water depth on the productivity for single and double basin double slope glass solar stills. Desalination, 359, 82-91.

[6] Almeida de Souza Marco A., Gomes Monteiro Patrícia C., Silveira Brandão Cristina C., Bernardes Ricardo S. (1999) Desinfecção solar: proposta de metodologia de estudo de viabilidade e determinação dos parâmetros básicos; Apresentado em: Congresso Brasileiro de Engenharia Sanitária e Ambiental, 20 Feira Internacional de Tecnologias de Saneamento Ambiental, 3, Rio de Janeiro, 10-14 mai.

[7] Hermosillo V, Juan J. (1995). Potabilización de Agua; Notas sobre el curso de Energía Solar capítulo 11. Instituto Tecnológico y de Estudios Superiores de Occidente, Jalisco, p. 131. Consultado el 25 de junio de 2015 en http://www.solartronic.com/download/curso_iteso.pdf

[8] A.A.F. Al-Hamadini, S.K. Shukla (2011). Water distillation using solar energy system with Lauric acid as storage medium, International Journal of Energy Engineering, 1, 1-8.

[9] K. Swetha, J. Venugopal (2011). Experimental investigation of a single slope solar still using PCM, International Journal of Research in Environmental Science and Technology, 1, 30-33.

[10] A.A.F. Al-Hamadini, S.K. Shukla (2014). Modelling of solar distillation system with phase change material storage medium. Thermal Science, 18, 347-362.

[11] Soares Clarissa, Sens Mauricio L., Emmendoerfer M. (2003). Produçâo de água potável através de destilaçâo solar natural, p. 15. Consultado el 18 de junio de 2010 en: http://www.bvsde.paho.org/bvsacd/abes22/cxxxiv.pdf

[12] Unidad de Planeación Minero Energética; Instituto de Hidrología, Meteorología y Estudios Ambientales; IDEAM. (2005). Atlas de Radiación Solar en Colombia. Consultado el 14 de mayo de 2015 en http://www.upme.gov.co/Docs/Atlas_Radiacion_Solar/1_atlas_Rad iacion_Solar.pdf

[13] Pita, Edward G. (2005). Acondicionamiento de Aire: principios y sistemas. Editorial Cecsa, segunda edición, México, Capítulo 7: Psicrometría.

[14] Maradey C, Juan F. (2002). Termodinámica Aplicada. Universidad Industrial de Santander, Escuela de Ingeniería Mecánica Bucaramanga UIS. Bucaramanga, Capítulo 3: Sistemas aire - agua.

[15] Çengel Yunus A. y Boles Michael A. (2012). Termodinámica. Editorial Mc Graw Hill, quinta edición, México, Capítulo 14: Mezclas de Gas - Vapor y Acondicionamiento de Aire.

[16] Al-Hayek, I. and Badran, O.O. (2004). The effect of using different designs of solar stills on water distillation. Desalination, 169 (2) pp. 121-127.

[17] Abdul J, N. K. and Ahmad M, H. (2009). Performance correlations for basin type solar stills. Desalination, 249 pp. $24-28$.

[18] Zaki, G. M.; Al-TURKI, A. and Al-Fatani M. (1992). Experimental investigation on concentrator-assisted solar-stills. International Journal of Sustainable Energy, Vol. 11, Issue 3 \& 4, pp. 193 - 199.

[19] Rahul Dev; Singh, H. N. and Tiwari, G. N. (2011). Characteristic equation of double slope passive solar still. Desalination, 267 pp. 261 $-266$.

http://www.pubmedcentral.nih.gov/articlerender.fcgi?artid=306129 $8 \&$ tool=pmcentrez\&re ndertype $=$ abstract. 